\title{
Explaining China's Popularity in the Middle East and Africa
}

Accepted for publication by Third World Quarterly, 26 Feb 2019

\begin{abstract}
China enjoys considerable popularity in the Middle East and Africa, not only among elites but also at street level. This article draws on international relations theories to explain this general pattern, as well as intra- and interregional variation. Every approach has something to contribute, but international political economy more so than realism. Constructivist theories are particularly useful in explaining China's popularity in the Middle East and Africa.
\end{abstract}

\section{Acknowledgements}

Thanks to the anonymous reviewers, Raphael Bradenbrink, Ivan Manokha, and the students of the MSc in Global Governance and Diplomacy for helpful suggestions and feedback.

\section{Contact Details}

Dr. Jörg Friedrichs

Associate Professor in Politics

Department of International Development

Queen Elizabeth House

3 Mansfield Road

Oxford OX1 3TB, England

joerg.friedrichs@qeh.ox.ac.uk 


\title{
Explaining China's Popularity in the Middle East and Africa
}

\begin{abstract}
China enjoys considerable popularity in the Middle East and Africa, not only among elites but also at street level. This article draws on international relations theories to explain this general pattern, as well as intra- and interregional variation. Every approach has something to contribute, but international political economy more so than realism. Constructivist theories are particularly useful in explaining China's popularity in the Middle East and Africa.
\end{abstract}

\section{Introduction}

China enjoys considerable popularity in the Middle East ${ }^{1}$ and $\mathrm{Africa}^{2}$, not only among political and business elites but also among ordinary people. All Middle Eastern and African regimes (including those hostile to one another, like Iran and Saudi Arabia) are on friendly terms with Beijing. Every year, opinion polls confirm China's popularity at street level.

A common explanation is that Beijing offers aid "with no strings attached." While this is persuasive at elite level, it cannot explain China's popularity among popular masses who might benefit from conditionality to fight corruption or promote human rights. Why, then, is China

\footnotetext{
${ }^{1}$ The region extending from Morocco to Iran, including the Mediterranean countries of North Africa and the Arab-majority countries of West Asia. Israel and Turkey are not included.

${ }^{2}$ All countries of the African continent except for the Mediterranean states of North Africa, which are seen as part of the Middle East.
} 
so popular in the Middle East and Africa? Is it for political reasons? Is it for economic gain? Is it for cultural reasons? Is it for one reason, or is it for a combination of reasons?

The article starts by demonstrating that China is indeed popular in the Middle East and Africa, both at the mass and at the elite level. Variation within either region, as well as between them, is explored. Next, I assess possible explanations. As Chinese popularity is a big-picture phenomenon, I resort to international relation theories to explain it. In doing so, I consider theories from three broad approaches: realism, international political economy (IPE), and constructivism. Under each rubric, I assess a range of particular theories. Every approach has something useful to contribute, but realism less so than IPE. Constructivist approaches appear most useful in explaining China's popularity in the Middle East and Africa.

Subsequently, I consider "dogs that do not bark." How is it possible for China to get away with "neocolonialism" and harsh treatment of Uyghur Muslims without suffering too much reputational damage in the Middle East and Africa? Once again, constructivism is most helpful to answer this question but other theories can also make significant contributions.

\section{China's Positive Image}

In this section, I present results from the Pew Global Attitudes Survey and other mass opinion surveys. Survey after survey confirms that, unlike in the West, mass opinion about China is remarkably positive in developing countries (e.g. Pew Research Center 2017, 2018). In the Middle East and Africa, this has not only been true of Pew surveys for many years. Many other opinion surveys point in the same direction. Next, I turn to elite attitudes. While there are few elite surveys (except Sautman and Yan 2009, Fioramonti and Kimunguyi 2011), there 
is other evidence to confirm that political and business elites in the Middle East and Africa hold China in high esteem. Finally, I explore cross-country variation in mass opinion and elite attitudes. As we will see, China is more popular in some countries than in others.

\section{Opinion surveys}

For decades, the Pew Research Center has polled hundreds of thousands of people across the Middle East and Africa, as well as other world regions. Among many other questions, people have been asked for their opinions of China. As a baseline for comparison, it is useful to present these opinions alongside attitudes towards the United States (Table 1).

\begin{tabular}{|l|l|l|l|l|}
\cline { 2 - 5 } \multicolumn{1}{c|}{} & \multicolumn{2}{c|}{ Opinion of China } & \multicolumn{2}{c|}{ Opinion of the United States } \\
\cline { 2 - 5 } \multicolumn{1}{c|}{} & \multicolumn{1}{c|}{ Favorable } & Unfavorable & Favorable & \multicolumn{1}{c|}{ Unfavorable } \\
\hline Middle East & $50 \%$ & $34 \%$ & $29 \%$ & $63 \%$ \\
\hline Africa & $71 \%$ & $15 \%$ & $75 \%$ & $14 \%$ \\
\hline
\end{tabular}

Table 1: Opinion of China and the USA, 2005-2018. ${ }^{3}$

As the data shows, China is popular in the Middle East and even more so in Africa. Let us compare this with opinions of the United States as the incumbent superpower. In the Middle

\footnotetext{
${ }^{3}$ Source: http://www.pewglobal.org/, last accessed 19 December 2018. Average values from all country-years for which data are available (7 Middle Eastern and 11 African countries).
} 
East, people regard China much more favorably than the United States. In Africa, the pattern is different: people are equally positive about China and the United States.

Interestingly, the level of Chinese popularity has recently converged between the two regions. China appears to be popular with about $50-60 \%$ of the people polled (Figure 1).

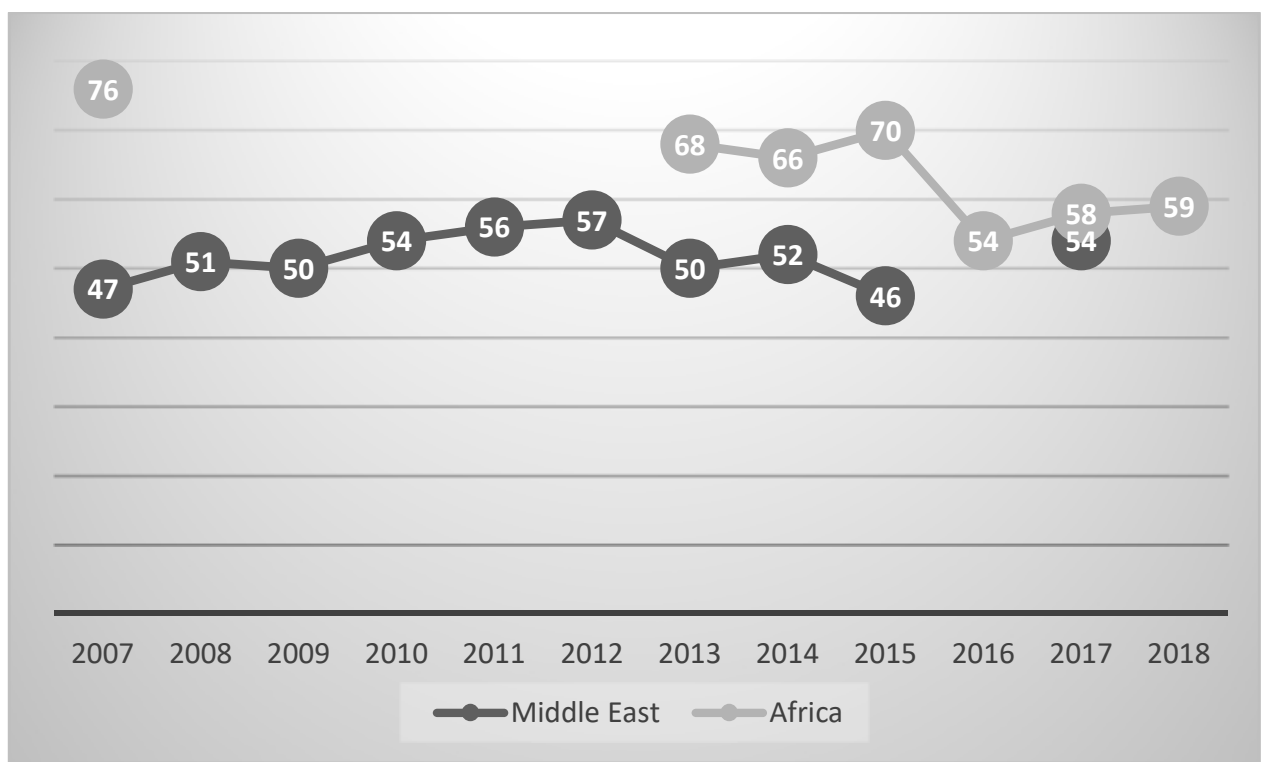

Figure 1: Favorable Opinion of China. ${ }^{4}$

Table 2 shows that people in the Middle East, and even more so in Africa, see China's economic rise in a positive light. Views of China's military rise are more ambivalent, with Africans taking a positive view but people in the Middle East rather skeptical. Yet, Pew (2018, 52) have found only one country where a majority would prefer China as the world's leading power: Tunisia, with $64 \%$ favoring China versus $26 \%$ favoring the United States.

\footnotetext{
${ }^{4}$ Average values for all years where at least three data points are available.
} 


\begin{tabular}{|l|l|l|l|l|}
\cline { 2 - 5 } \multicolumn{1}{c|}{} & \multicolumn{2}{c|}{ China's economic rise } & \multicolumn{2}{c|}{ China's military rise } \\
\cline { 2 - 5 } \multicolumn{1}{c|}{} & \multicolumn{1}{c|}{ Good thing } & \multicolumn{1}{c|}{ Bad thing } & Good thing & \multicolumn{1}{c|}{ Bad thing } \\
\hline Middle East & $55 \%$ & $30 \%$ & $31 \%$ & $43 \%$ \\
\hline Africa & $76 \%$ & $13 \%$ & $52 \%$ & $26 \%$ \\
\hline
\end{tabular}

Table 2: Opinions on China's economic and military rise, 2005-2014. ${ }^{5}$

Other surveys point in a similar direction. The Arab Opinion Index finds that only $32 \%$ of Arabs dislike China's foreign policies towards the region, compared to $79 \%$ for US policies (Arab Center 2018, 27). In 2016, still under the Obama administration, 42\% disliked Chinese and 75\% US foreign policies (Arab Center 2017, 11). According to the 2013 Arab Barometer, Arabs have a stronger desire for better economic relations with China (59\%) than with the USA (49\%). ${ }^{6}$ According to the 2011 Arab Public Opinion Survey, 23\% of Arabs would prefer China as the world's only superpower whereas only $7 \%$ would prefer the United States (Telhami 2013, 175). The 2008 and 2014/5 rounds of the Afrobarometer point in a similar direction for Africa (Hanusch 2012, Keuleers 2015, Afrobarometer 2016).

\footnotetext{
${ }^{5}$ Source: http://www.pewglobal.org/, accessed 1 September 2017. Average values from all country-years for which data are available (7 Middle Eastern and 10 African countries). Note that the questions about China's economic and military rise were discontinued in 2015. ${ }^{6}$ Questions 7001 and 7009, http://www.arabbarometer.org/, accessed 7 January 2019.
} 


\section{Elite attitudes}

All Middle Eastern countries have warm diplomatic and strong business relations with China (Olimat 2014, 2016). This includes even countries hostile to one another. Iran and Saudi Arabia are enemies, but both enjoy close political and business relations with China (Scobell and Nader 2016). Western sanctions against Iran have the ironic effect of pushing Tehran closer to Beijing, even though Beijing is unable to fully reciprocate the overtures because of the compulsion to act as a "responsible power" (Hong 2014). Middle Eastern countries, and especially Iran, are keen beneficiaries of China’s Belt and Road Initiative (Kamel 2018).

Likewise, all African countries are on good terms with China (Shinn 2016, 50-52). Beijing even manages to be friendly with countries that are at loggerheads with one another. China is on good terms with both Sudan and South Sudan—despite the fact that relations between them are tense. China is also friendly with so-called "pariah regimes." Thus, China and Zimbabwe are on good terms despite, or precisely because of, Zimbabwe's fraught relations with the West. As of 2019, Swaziland is the last African country to recognize Taiwan.

Middle Eastern and African politicians and entrepreneurs mingle with their Chinese counterparts at glamorous regional forums (Alden and Alves 2017). The Forum on China-Africa Cooperation, FOCAC, has met seven times since its inauguration in 2000, including three times at summit level with many heads of states attending. The China-Arab States Cooperation Forum, CASCF, was set up in 2004 and meets every two years. Middle Eastern entrepreneurs thrive in Chinese business hubs, from Yiwu in Zheijiang to Guangzhou in Guangdong and further to Ningxia, an autonomous region where the Muslim Hui are the titular nation (Simpfendorfer 2011, Ho 2013). According to an expert, there are two million Chinese in Africa and half a million Africans in China, mainly in Guangzhou (Bodomo 2018, 66). 
In the 2000s, an elite survey in Kenya and South Africa found broad support for "no strings attached" investment from China among politicians, businesspeople, and opinion leaders (Fioramonti and Kimunguyi 2011). Around the same time, a team of scholars surveyed university students in nine African countries. More than anywhere else, African students are incoming elites. At the same time, like everywhere else, students tend to be critical in their attitudes. One might therefore expect African students to be more critical of China than the population at large. Yet, their opinions of China were found to be positive (Sautman and Yan 2009).

\section{Variation}

As one might expect, there is variation. Just because there is a general trend does not mean that there cannot be outliers. Table 1 shows high approval for China in the Middle East, but a majority in Jordan and Morocco holds unfavorable views. ${ }^{7}$ Table 1 shows even higher approval in Africa, but in South Africa majority support for China is waver-thin. ${ }^{8}$

While China is generally popular in Africa, Chinese merchants and other economic migrants are resented in many localities (Hanauer and Morris 2014, 67-71). Especially in small countries like Botswana and Malawi, politicians sometimes endanger friendly relations with Beijing by playing the anti-Chinese card (ibid., Sautman and Yan 2009, 752-754). In Zambia, opposition leader Michael Sata used to mobilize against Chinese businesses. He did so in the 2006 presidential election - and lost. In 2011, he won-but on a somewhat less radical platform. Upon entering office, he retracted his anti-Chinese populism (Hess and Aidoo 2014).

\footnotetext{
${ }^{7}$ Jordan: 43\% favorable, 54\% unfavorable; Morocco: 26\% favorable, 29\% unfavorable.

${ }^{8}$ South Africa: $45 \%$ favorable, $40 \%$ unfavorable.
} 
These are exceptions confirming the rule, and they are largely ineffectual. In the Middle East, even such exceptions are rare. Some anti-Chinese mobilization has occurred in Algeria, but without any significant effect (Hayoun 2013). In Libya, however, the ouster of Muammar Gaddafi in 2011 jeopardized Chinese investment worth 18 billion US dollars, and Beijing had to evacuate 36,000 workers from the country (Erian 2012).

\section{Explaining China's popularity}

Despite variation, China's popularity in the Middle East and Africa is a macro rather than a micro phenomenon. To explain a broad phenomenon like this, regression analysis (Hanusch 2012, Keuleers 2015) can reveal personal motivators but takes us only so far. As an alternative, it seems promising to turn to big-picture theories. For example, there is literature on the relationship between public opinion and foreign policy (Soroka 2003, Baum and Potter 2008, Kertzer and Zeitzoff 2017). However, that literature refers to the nexus between domestic public opinion and the foreign policy making of late capitalist democracies.

Such literature cannot tell us how the political and cultural outreach of a rising economy like China affects public opinion and elite attitudes in developing countries. The latter question pushes us into international relations (IR) terrain. As we will see, IR theories can help us explain not only the general pattern of Chinese popularity in the Middle East and Africa, but also intra- and interregional variation. In what follows, IR theories are organized according to three approaches: realism, international political economy (IPE), and constructivism. 


\section{Realism}

Realist theories of international relations posit that state power is what makes the world go round. In this section, I shall consider two different schools of realism. Conventional realism looks at the state system through the lens of great powers. Conventional realists either assume that the rise of China leads to a new balance of power; or that the rise of China, as well as the relative decline of the USA, heralds a power transition. As we will see, the effect on China's popularity in the Middle East and Africa is indeterminate. Subaltern realism, by contrast, adopts the lens of domestically insecure developing countries. From the perspective of such vulnerable regimes, China can offer greater stability than Western partners. This is likely to contribute to China's popularity with political elites in the Middle East and Africa.

\section{Conventional realism}

Conventional realist theories are designed to account for configurations of power. They can either account for a homoeostatic balance of power whereby countries strike alliances that cancel each other out (Morgenthau 1948, Waltz 1979), or for power transitions whereby history is a succession of hegemonic state systems (Organski 1958, Gilpin 1981).

Given China's rise and America's relative decline, power transition theory is clearly relevant. According to this theory, the most powerful state in the system acts as hegemon. Periods of hegemonic stability are followed by periods of hegemonic decline, eventually leading to wars that either confirm the old order or establish a new one (Gilpin 1981). 
In line with power transition theory, so-called offensive realists risk a prediction: China's rise cannot be peaceful in an international system dominated by the USA. They claim that a rising China is bound to become increasingly assertive. This, they argue, will be unacceptable to the United States, and therefore a showdown is unavoidable (Mearsheimer 2006). Harking back to ancient Greece, this has become known as the Thucydides trap (Alison 2017).

Neoclassical realists agree with offensive realists that the international system shapes state behavior, but they also emphasize the importance of domestic factors (Rose 1998). In their view, Chinese leaders operate not only on systemic but also on domestic imperatives and constraints when engaging in, or refraining from, aggressive posturing against the United States as the incumbent hegemon in the state system (Sørensen 2013, Schweller 2014).

The domestic focus of neoclassical realists allows them to appreciate the strategic importance of the Middle East and Africa in the Chinese calculus. China needs raw materials, notably oil, to develop its economic and military capabilities. Accordingly, Beijing engages in a scramble for resources from Middle Eastern and African states. That scramble is driven not only by power competition with the United States but also by the needs of Chinese state-owned businesses and other key domestic stakeholders (Keskin and Braun 2016).

All of this might be helpful to explain and predict Chinese conduct, but it offers little to explain what we are interested in: namely, China's popularity in the Middle East and Africa. If anything, China's rise and America's decline should lead to a situation where, in relative terms, it becomes easier for Beijing and harder for Washington to deal with weak allies arbitrarily. As China's rise progresses, therefore, it should make Middle Eastern and African leaders increasingly nervous about Beijing (and decreasingly so about Washington). 
Thus, power transition theory would lead us to expect that China's rise should make Beijing less popular in weak developing countries. Not so for theories that see the state system reverting to a balance of power. From this perspective, weaker countries prefer great power competition to a situation where a single superpower can push them around. As long as China is weaker than the USA, political elites in developing countries have little reason to fear China while they do have reason to be concerned about US-led military interventionism. ${ }^{9}$

On balance, expectations derived from conventional realism are indeterminate. Power transition theory suggests that China's popularity among political elites in the Middle East and Africa should be declining, whereas balance of power theory would suggest otherwise.

\section{Subaltern realism}

Subaltern realism (Ayoob 2002) is an adaptation of realism to the conditions of developing countries. It starts from the observation that most political regimes in the developing world are vulnerable to domestic unrest and engaged in unfinished projects of nation building. Understandably, international partners willing to stabilize incumbent regimes are more welcome than, say, Western partners eager to "empower" civil society and the political opposition. When compared to more conventional realist theories, this provides a relatively straightforward explanation for why Middle Eastern and African leaders embrace China.

The reasons are obvious. In Libya, Beijing supported Ghaddafi until his ouster became inescapable. In Egypt, Beijing regretted the downfall of Mubarak and, unlike the USA and other Western countries, did not jump on Morsi's bandwagon. Instead, it waited until the situation

\footnotetext{
${ }^{9} 84 \%$ of Arabs see the USA but only $28 \%$ China as a threat (Arab Center 2018, 30).
} 
had stabilized and then supported the restorationist regime of el-Sisi. In Syria, China has supported the beleaguered President Bashar al-Asad for many years. Beijing has also been willing to sustain international pariahs like Omar al-Bashir in Sudan and Robert Mugabe in Zimbabwe. China may have supported the 2017 palace coup against Mugabe, but did so only in the last moment and in the interest of political stability. China continues to support the ZANU-PF regime under Emmerson Mnangagwa (Clover, Feng, and Pilling 2017).

Unsurprisingly, this is highly welcome to Middle Eastern and African elites. Chinese support reduces their dependency on the United States and other Western "partners" who might want to "empower" civil society and oppositional politicians against incumbent regimes.

\section{International political economy}

While realist approaches focus on state power and political elites, international political economy highlights the importance of markets and business elites. In this section, I discuss three IPE theories. First, liberal theory focuses on the influence of business lobbies and can explain pro-Chinese attitudes where business interests benefit from trade with China. Second, interdependence theory focuses on symmetrical or asymmetrical trade relations and can explain attitudes towards China not only for elites but also for popular masses. Third, I discuss $d e$ pendency theory which retains a certain influence in development discourse. 


\section{Liberal theory}

The liberal theory of international relations rests on the premise that politicians are not autonomous in formulating foreign policies but must look to the preferences of influential business elites. To the extent that politicians depend on popular support and not only the support of business elites, ordinary people may also influence foreign policies. However, liberal theory normally focuses on business lobbies rather than popular masses (Moravcsik 1997, 2011).

Liberal theory predicts that, the more influential business elites in Country A stand to gain from cooperation with Country B, the more interested Country A will be in such cooperation; conversely, the more influential business elites in Country A stand to lose from cooperation with Country B, the less interested Country A will be in such cooperation.

In many Middle Eastern and African countries, the extractive sector, and notably the oil industry, looms large. We may hypothesize that China will be popular among elites in such resource rich countries because mineral interests will lobby for strong China links in order to benefit from Chinese trade and investment. Conversely, China will be less popular in resource poor countries, especially where there are important sectors such as the textile industry that are bound to incur significant losses from Chinese competition.

By and large, these expectations are met. Oil exporting countries like Angola, Nigeria, Sudan, and Equatorial Guinea lean towards China. In resource poor countries, support for China is contingent on political circumstances: where the regime relies on business interests that benefit from trade with China, political elites will be friendly towards China. In countries where the regime relies on business interests that feel threatened by trade with China, political elites 
will be more protectionist and display a less friendly attitude towards Beijing. This might explain why China is less popular in countries like Jordan, Morocco and South Africa, all of which have significant manufacturing industries that require a level of state protection.

\section{Interdependence theory}

Interdependence theory (Keohane and Nye 1977) holds that international trade and other forms of cross-country exchange create transnational linkages that are costly to disrupt. While transnational linkages always create mutual sensitivities and vulnerabilities, the theory speaks of "asymmetrical interdependence" when Country A benefits more from the relationship, and is more vulnerable and sensitive to disruptions, than Country B.

Table 3 provides an aggregate picture of Middle Eastern and African trade, comparing data from the end of the Cold War with the most recent IMF data. In 1991, Middle Eastern and African countries traded mainly with the West: trade with the EU was dominant; trade with the USA was important; trade with China was insignificant. In 2017, trade with China outweighed trade with the USA, although the EU remained the most important partner. 


\begin{tabular}{|c|c|c|c|c|}
\hline & \multicolumn{2}{|c|}{ Middle East } & \multicolumn{2}{|c|}{ Africa } \\
\hline & 1991 & 2017 & 1991 & 2017 \\
\hline Exports to China & $1 \%$ & $12 \%$ & $0 \%$ & $15 \%$ \\
\hline Imports from China & $2 \%$ & $15 \%$ & $1 \%$ & $16 \%$ \\
\hline Exports to USA & $11 \%$ & $6 \%$ & $15 \%$ & $6 \%$ \\
\hline Imports from USA & $10 \%$ & $8 \%$ & $8 \%$ & $5 \%$ \\
\hline Exports to EU & $34 \%$ & $16 \%$ & $39 \%$ & $21 \%$ \\
\hline Imports from EU & $46 \%$ & $25 \%$ & $44 \%$ & $25 \%$ \\
\hline
\end{tabular}

Table 3: Exports and imports, 1991 and 2017. Source: IMF Direction of Trade Statistics, http://data.imf.org, last accessed 18 December 2018

A closer analysis suggests an important asymmetry: Middle Eastern and African trade appears less important for China than the other way round. $12 \%$ of Middle Eastern exports and $15 \%$ of Middle Eastern imports are with China, but only 5\% of Chinese exports and $6 \%$ of Chinese imports are with the Middle East. In the African case, $15 \%$ of exports and $16 \%$ of imports are with China but as little as $3 \%$ of Chinese exports and $4 \%$ of Chinese imports are with Africa. If this is true for the Middle East and Africa as a whole, it is even more so for individual countries. There are about 70 countries across the Middle East and Africa, and they all deal with a remarkably unified and centralized China.

One might be tempted to infer that interdependence is asymmetrical, with the Middle East and Africa at the weaker end. However, this would be premature. China heavily relies on oil and other commodities from the Middle East and Africa, which creates a counter-dependence. China imports $45 \%$ of its oil from the Middle East and another $18 \%$ from Africa. The 45\% of Chinese oil imported from the Middle East amounts to only $18 \%$ of Middle Eastern 
oil exports. ${ }^{10}$ Since China needs the Middle East more for its oil imports than the Middle East needs on China for its oil exports, this time the interdependence works against China.

In the African case, China imports $18 \%$ of its oil from Africa but this amounts to as much as $35 \%$ of African oil exports. Despite this greater dependence, there is a counter-dependence playing to China's disfavor. Especially in Africa, more than in the Middle East, Chinese companies have "sunk" significant investment in extractive infrastructure. Unfortunately for Chinese investors, foreign capital invested in the petroleum sector of oil exporting countries is always at risk of expropriation-a lesson Western investors had to learn the hard way in the 1970s when petroleum industries were nationalized (Keohane 1984, 217-240).

On balance, it seems impossible to reach any definitive conclusion regarding the degree of symmetry or asymmetry of interdependence at the regional level. Indeed, the asymmetries point in opposite directions and cancel each other out. Nevertheless, it is evident that some countries are more dependent on China than others. Most obviously, dependence is high for so-called "pariah regimes" like Sudan and Equatorial Guinea which would struggle to sell their oil on the world market and to find investors in their petroleum sector. Given Western sanctions, Iran has also struggled to sell its oil to clients other than China. The same applies to pariah regimes that rely on mining industries other than petroleum, like Zimbabwe.

Patterns of economic interdependence are also highly asymmetrical in countries that lack oil or other commodities to balance their trade with China. While resource rich countries can rely on commodity exports to counterbalance the importation of Chinese goods, resource poor countries run enormous trade deficits, exacerbating their dependence.

${ }^{10}$ Calculations based on BP $(2018,24)$. 
How does all of this affect China's popularity? While "pariah regimes" can keep the public friendly towards Chinese patrons, the public in less authoritarian countries may resent dependence on China. This happens especially in countries where imported Chinese consumer goods threaten to outcompete domestic manufacturing industries. While consumers everywhere benefit from cheap and affordable Chinese goods, the importation of such goods can crowd out domestic production. When that happens, ordinary people lose their jobs.

Unsurprisingly, therefore, the strongest anti-Chinese sentiment is observed in countries that, on the one hand, have little or no extractive industry and that, on the other hand, have manufacturing industries threatened by Chinese imports. Indeed, the Middle Eastern and African countries where China is least popular are precisely those that have limited natural resources and significant industrial production. In the Middle East, the countries where people have the most negative attitude about China are Jordan (54\%), Egypt (41\%), and Lebanon (40\%). In Africa, the most negative attitude about China is found in South Africa (40\%). ${ }^{11}$

All of these countries are net importers of raw materials, have a fairly advanced workforce, and have significant manufacturing industries endangered by trade with China.

\section{Dependency theory}

From a developing country perspective, asymmetrical interdependence is often experienced as dependence. Perceived dependence can lead to despair; thus, the original version of de-

${ }^{11}$ Source: http://www.pewglobal.org/, last accessed 19 December 2018. 
pendency theory was about an impoverished and underdeveloped periphery seen as hopelessly dependent on the capitalist core (Amin 1976). It can also lead to rage, with developing countries aiming to subvert an unequal and inequitable capitalist order (Krasner 1985).

From a dependency perspective, trade with China has a welcome effect for the Middle East and Africa: it has reduced dependence on the West (Table 3). Accordingly, dependency theorists celebrate the rise of Chinese trade with Africa as a challenge to western capitalism and US global hegemony (Campbell 2008). For obvious reasons this is water on China's mills. Beijing tirelessly highlights its credentials as a third world leader rescuing developing countries from the western stranglehold and offering a superior development model.

Empirically speaking, however, there is a problem. From a dependency perspective, the standard policy prescription for peripheral developing countries is that they should pursue a mercantilist strategy of import substitution, producing and exporting as many goods as possible rather than importing and consuming them (Cardoso and Faletto 1979). As a matter of fact, China has been highly successful with this strategy-embracing the liberal international economic order while at the same time pursuing mercantilist goals. In doing so, China has moved up the industrial food chain and is hardly a developing country any longer.

Now that China is part of the industrial core, developing countries have every reason to be on their guard. Beijing's "economic statecraft" (Norris 2016) in pursuit of national interests places developing countries at the receiving end of Chinese neo-mercantilist practices, as is particularly evident in the energy sector (Lind and Press 2018). From a dependency perspective, China should become less popular the more it moves up the industrial food chain.

This is not to deny that, understandably, Middle Eastern and African elites might be receptive to the financial largesse associated with Chinese economic statecraft. A genuine dependency 
perspective, however, would lead us to expect domestic backlash against this, not only from the political opposition but also from the wider population. Yet, Beijing's Belt and Road Initiative remains largely uncontested in the Middle East (Kamel 2018) and there has been little backlash against it in Africa, apart from subdued grumblings (Pilling and Peng 2018).

In short, the evidence flies in the face of dependency theory-unless, that is, we take the jaundiced view that the United States and European countries are exploitative per definition, whereas China cannot possibly be exploitative because it is not western. This view is hardly tenable from a theoretical or empirical perspective, but it remains a highly popular trope in pro-Chinese and anti-Western discourse. Echoing a speech by Chinese President Xi Jinping, an Ethiopian-Chinese pair of authors find: "In fact, the Chinese have no gene in their blood to invade Africa and it is crystal clear that unlike China, the Western world has had an influential history in the African continent" (Addis and Zuping 2018, 357, 365).

As we shall see further below, when discussing the question of Chinese neocolonialism, the dependency perspective is relevant not so much as a theory of IPE but rather as a source of development discourse and as a framework for constructing Chinese popularity.

\section{Constructivism}

Social constructivism is about how people make sense of what they observe and experience; as well as how shared frameworks of meaning, sometimes called cultures, influence the way people act and interact (Berger and Luckmann 1966). In what follows, I consider three con- 
structivist approaches: the social theory of international relations; soft power; and intercultural theory. As we will see, constructivism can significantly contribute to explaining China's popularity in the Middle East and Africa, including variation across the regions.

\section{Social theory of international relations}

One of the fundamental constructivist insights is that international anarchy is "what states make of it" (Wendt 1992). Every country, as represented by its citizens and specifically its decision makers, must figure out whether the citizens and decision makers of other countries are its friends or its enemies. At the same time, decision makers are conscious that other countries do the same (Wendt 1999). To make international friends, they are therefore eager to present their country and its citizens in the most sympathetic light possible.

In this spirit, Chinese decision makers foment positive international relations by highlighting commonalities with other countries. For example, former Prime Minister Wen Jiabao stated in November 2009: "China and the Arab countries share a lot of similarities, as both are developing countries with long histories, brilliant civilizations and glorious cultures; both were humiliated and colonized by Western powers in the modern times; and both are seeking national revitalization in the new era" (cited in Sun and Zoubir 2015, 910).

According to Mao-era rhetoric, China's role in the developing world is uniquely benign and based on South-South solidarity, non-interference, mutual benefit, international friendship, unconditional aid, and shared memories of suffering from Western imperialism (Strauss 2009). In this spirit, Beijing ingratiates itself with Middle Eastern and African leaders by highlighting that China abstains from unwanted interference in their domestic affairs and 
does not attach any political strings to development aid. African leaders reciprocate by not questioning Beijing's handling of Chinese domestic affairs (Shinn 2016).

Implicit in all of this, there is an ostentatious contrast: While the Middle East and Africa have had and still have a difficult time with the formerly colonial West, China is an all-time friend and development partner. In this context, Beijing can highlight China's strong record of economic growth to boost the country's credentials as a developmental model.

In reality, Middle Eastern and African experiences with China are of course not uniformly positive. Nevertheless, both sides deny or paper over any evidence that might countervail the official win-win narrative. Beijing is eager to project a positive image because it understands that this may lock in friendly relations with the Middle East and Africa.

\section{Soft power}

Some constructivists understand China's positive image in terms "soft power." According to Joseph Nye's authoritative definition, soft power is "the ability to get what you want through attraction rather than coercion or payments." Unlike hard power, soft power arises "from the attractiveness of a country's cultures, political ideals, and policies" (Nye 2004, x).

Beijing has for a long time engaged in public diplomacy to promote Chinese soft power (Wang 2008, Zhu 2013). Some have claimed that this has enormous effect (Kurlantzick 2007). Others stress that, despite significant investment, Beijing is not getting a decent return 
(Shambaugh 2015). Nye himself cautions that soft power is not so much something a government can buy but rather something a society must earn (Nye 2013). Given the lack of freedom in China, he argues, Chinese soft power is no match for America's (Nye 2015). ${ }^{12}$

Indeed, Chinese soft power appears weaker than America's (Tella 2016). English remains the uncontested lingua franca, and Hollywood blockbusters are incomparably more popular than Chinese movies. Not too many students learn Mandarin, and there are no global Chinese blockbusters (Stout 2016). On balance, it seems, Chinese culture has limited attraction in the Middle East and Africa. China has many strengths, but soft power is not one of them.

\section{Intercultural theory}

The intercultural theory of international relations (Friedrichs 2016) is a constructivist theory that understands countries and their societies as characterized by three distinct cultures of self-worth: honor, face, and dignity. It posits that each way of establishing self-worth leads to a distinct relational dynamic. We may leave aside dignity culture as represented by the West, as China represents face culture and the Middle East and Africa, mostly, honor culture.

Alongside Korea and Japan, China is the paradigm case of a face culture (Hu 1944, Gries 1999, He and Zhang 2011). Face is "the respectability and/or deference which a person can claim for himself from others, by virtue of the relative position he occupies in his social network and the degree to which he is judged to have functioned adequately in that position as well as acceptably in his general conduct" (Ho 1976, 883). Such "social anchoring of self in

\footnotetext{
12 The lack of freedom in China is less of a problem than Nye thinks because, according to opinion polls, people in African and Middle Eastern countries have surprising confidence in China's respect for personal freedoms (Pew Research Center 2018, 56-57, 2017, 28-30).
} 
the gaze of others" (Qi 2011) yields relatively clear and consistent status hierarchies. People know their place and accept that, ultimately, their self-worth depends on significant others. While this limits personal autonomy, it makes society more stable.

If China represents the face culture par excellence, the Middle East is the epitome of honor culture. Honor is "the value of a person in his own eyes, but also in the eyes of his society. It is his estimation of his own worth, his claim to pride, but it is also the acknowledgment of that claim, his excellence recognized by society, his right to pride" (Pitt-Rivers 1965, 21). Arab notions of honor permeate Muslim societies to such an extent that Islam has become intertwined with honor culture (Stewart 1994). Historically, Sub-Saharan Africa has similarly been home to tribal honor cultures, which remain recognizable (Iliffe 2005).

Honor is a "right to respect" (Stewart 1994, 21), which implies status uncertainty and a high risk of conflict. The reason is that, in an honor culture, self-worth needs to be asserted and, when necessary, defended against real or perceived rivals. By comparison, conflict is less rife in a face culture because, when status rests on group consensus, self-worth is a matter of discreet negotiation with significant others rather than peer contestation.

With due adjustments for the transition from individual self-worth to that of groups, and further to that of entire nations, the intercultural theory of international relations makes the following predictions for relations between face and honor cultures (Friedrichs 2016, 85).

A. When the face culture has higher status, relations tend to be positive and stable because face cultures respect the self-worth of inferiors.

B. Relations are more difficult in situations of symmetry because the honor culture may act aggressively due to status anxiety. 
C. When the honor culture has higher status, lack of respect for the face culture may lead to humiliation and resentment, disrupting relations.

Chinese-African relations are a case in point of Proposition A. From a Chinese perspective, there is no question about China's superior status. As Jacques (2012) notes, China is a "civilization-state" with a "Middle Kingdom mentality." Noblesse oblige. Assured in its superiority, Beijing offers African and Middle Eastern states ostentatious recognition and respect (Alden and Large 2011, 21). Africans appreciate such deference precisely because they normally enjoy less respect. At an event in 2008, a group of African ambassadors declared: "China gives Africans more respect than they get from the West" (Brautigam 2009, 68). This translates into better diplomatic relations and a more positive perception of China.

In the Middle East, leaders and societies are less inclined to take inferior status for granted. The following statement by a high official of the Saudi Chambers of Commerce is emblematic: "We are in a Catholic marriage with America. But we are also Muslims-we can have more than one wife" (cited in Fattah 2006). This sexist statement implies that, as "husband," Saudi Arabia stands above its "wives." Can China accept being seen as a secondary wife? Must China not show the Saudis who rules the roost? In anticipation of status contestation, people in the Middle East are already concerned about China's rise (Table 2). If and when such contestation becomes virulent, relations may become tense (Proposition B or C).

While there is a shared understanding about China's superior status in Africa, there is latent contestation in the Middle East. Based on this, intercultural theory can explain variation between Chinese popularity in Africa on the one hand, and the Middle East on the other. The theory would suggest that the convergence observed in Figure 1 should be short-lived. 


\section{Dogs that do not bark}

To assess further the utility of different international relations theories when it comes to explaining China's popularity in the Middle East and Africa, let us consider two "dogs that do not bark": the question of Chinese neocolonialism; and the Uyghur issue. Although Chinese conduct in the Middle East and Africa can be as egregious as, if not more than, Western conduct, and although the Uyghurs in China are treated more harshly than any Muslim minority in the West, only few people in the Middle East and Africa take issue with it.

This is partly because Beijing ensures that people in developing countries feel respected rather than humiliated. Beijing also knows that foreign elites value political and business cooperation with China, and uses this to make sure any anti-Chinese popular sentiment is neutralized. Once again constructivism turns out most useful — this time to explain why China is rarely singled out for neocolonialist conduct or harsh treatment of Uyghur Muslims.

\section{Chinese neocolonialism?}

Following Nkrumah (1965), critics often frame western conduct in developing countries as neocolonial. This is common not only for African but also for Western observers accusing the West of exploiting developing countries, perhaps not directly as in the colonial era but indirectly. In support of this claim, such critics allege (1) structural inequalities and unequal exchange; (2) Western states colluding with corrupt regimes; and (3) Western corporations providing insufficient opportunities for qualified labor in developing countries. 
If this is so, then it seems fair to ask why China does not get similar blame. Does China not exploit structural inequalities? Does Beijing not collude with corrupt regimes? Do Chinese companies offer more opportunities for qualified labor in developing countries?

First, China imports oil and other commodities in exchange for cheap consumer goods and investment in infrastructure. This amounts to a pattern of unequal exchange that is eerily familiar from colonial trade structures. Second, China routinely colludes with corrupt regimes, ensuring access to commodities by partnering with the likes of Iran, Sudan, Equatorial Guinea, and Zimbabwe. Third, Chinese labor practices are notoriously insensitive and include the controversial practice of relying on Chinese expats rather than local workers (Human Rights Watch 2011, Zhao 2014, 1043-1044). Only 7.6\% of contracts in China-funded projects go to local contractors, whereas the World Bank and other western-based multilateral development banks award 40.8\% of contracts to local contractors (Kynge 2018).

Despite all this, few in Africa and the Middle East lambast Chinese conduct as neocolonial. If anything, China is presented as empowering poor developing countries to tackle the neocolonial West (Addis and Zuping 2018). This is ironic because it allows China to get away with neocolonial practices while deflecting the blame to the "usual" Western suspects.

Constructivist theories are well placed to explain this. While people in Africa and the Middle East have unpleasant memories of Western colonialism, China has never colonized them. The charge of Western neocolonialism sticks, but the idea of Chinese neocolonialism seems farfetched. Beijing exploits this cognitive predisposition by constructing China in contrast with the formerly colonial West, fortifying the idea that China is different and better. 
Apparently, the actual conduct of foreign powers is of limited concern to many people in Africa and the Middle East. What really grates on them is a patronizing attitude. Western governments and businesses, as well as Western civil society, are notorious for trying to impose Western principles and values on developing countries. Such cultural imperialism is deeply humiliating. China, by contrast, does not impose anything. According to the Saudi Gazette, "China, unlike the US, appears to have no messianic illusions about its role in the world, passing no ideological judgment on its partners" (Saudi Gazette 2010).

While China is largely immune to the charge of neocolonialism, there was an interesting exception confirming this rule. In 2006, amidst popular protests against Chinese businesses, South African President Mbeki told a student audience that Africa had to guard against falling into a "colonial relationship" with China (BBC News 2006).

At the 2012 China-Africa Forum, Mbeki's successor Zuma took the opposite tack.

\footnotetext{
"We are particularly pleased that in our relationship with China we are equals and that agreements entered into are for mutual gain. This gathering indicates commitment to mutual respect and benefit. We certainly are convinced that China's intention is different to that of Europe" (Zuma, cited in Smith 2012).
}

Zuma made his 2012 statement in Beijing, in the presence of Chinese politicians and businessmen, evidently to score political points and solicit investment. This is in stark contrast with Mbeki's 2006 statement, which was aimed at dissatisfied Africans in Cape Town. Both politicians were trying to score points, but with different audiences in mind.

The example confirms that identity politics plays an important role (constructivism). At the same time, it also suggests that state interests (realism) and economic considerations (IPE) 
may be lurking behind identity politics. Being on good terms with China is not only about Afro-Asiatic friendship. It is also about political relations and economic gain.

\section{The Uyghur issue}

In China's western region of Xinjiang, Uyghurs are the largest ethnic group. Uyghurs struggling for greater autonomy or even independence have sometimes tried to enlist Muslim coreligionists in foreign countries for support. Beijing has been unwilling to cede control and has tried to undercut any foreign support for the Uyghurs (Friedrichs 2018, 2017). While China's treatment of Uyghurs has been harsh for a long time, at present hundreds of thousands if not more than a million of them live in internment camps (Ryan, Cave, and Ruser 2018).

One might expect China's treatment of Uyghurs to incite Islamic solidarity in Muslim-majority countries. One would further expect transnational solidarity to compel political leaders in such countries to embrace the Uyghur cause. One might expect this particularly for countries that claim religious leadership, such as Saudi Arabia and Iran (Frankel 2016, 578-581).

In reality, however, the Uyghur issue plays a limited role. Saudi Arabia, in particular, is a self-proclaimed leader of the Islamic world. It might want to support oppressed Uyghur Muslims. However, China receives 15\% of Saudi Arabia's oil (BP 2018, 24). Unlike the West, Beijing does not humiliate Riyadh for its human rights record and autocratic governance. Saudi Arabia reciprocates by refraining from interference in China's domestic affairs. In 2009, after a bloodbath in Xinjiang, Riyadh did not record any protestation. Such mutual "respect" enables both sides to continue business as usual (Al-Tamini 2014). 
Iran is another case in point. Ever since its 1979 revolution, the country has claimed to be a leader of the Islamic world. We might expect Tehran to speak up for the Uyghurs. In reality, however, this rarely happens because Beijing is too important for Tehran. Due to Western sanctions, China is indispensable as an importer of Iranian oil and investor in the country's petroleum sector (Hong 2014). The two countries are also engaged in military cooperation because each is targeted by a Western arms embargo. Mindful of its vital interest in good relations with China, Tehran has reined in covert support for Chinese Islamists ever since the mid-1990s (Garver 2006, 129-138). Iran's official response to the 2009 bloodbath in Xinjiang was remarkably subdued (Santana 2009). Islamist critics of China's repression of Uyghur Muslims are blissfully ignored by the regime (Shichor 2014, 127-128).

All things considered, it is apparent that state interests (realism) and business considerations (IPE) motivate elites in Muslim-majority countries to highlight the harmonious aspects in their relations with China (constructivism) rather than allowing religious or ethnic bonds with Uyghur Muslims to come in the way of gainful relations with China.

\section{Conclusion}

China is highly popular in the Middle East and Africa, not only among elites but also at street level. In this article, we have considered international relations theories to explain the general pattern of Chinese popularity, as well as variation between countries and across regions. Instead of pitting theories against each other, we have assessed the contribution each can make towards explaining China's popularity in the Middle East and Africa. 
Constructivist theories are particularly useful. The social theory of international relations shows how, in the absence of negative experience with China during the colonial era, people are more receptive to aspirational talk highlighting China's benign intentions. The intercultural theory of international relations successfully predicts variation across regions. When there is no status contestation, as between China and Africa, the theory predicts friendly relations. When there is risk of status contestation, as between China and the Middle East, it predicts that relations with China, as well as Chinese popularity, should be less stable.

IPE is very helpful to explain intra-regional variation. Liberal theory suggests that business elites who stand to gain (lose) from stronger links with China will lobby for (against) such links, and that a country's orientation towards China will depend on whether pro- or anti-Chinese business lobbies are more powerful. Interdependence theory is helpful in explaining why China is least popular in situations of asymmetrical interdependence, namely resource poor countries with trade deficits and internationally uncompetitive industries.

Conventional realism makes somewhat indeterminate predictions, but subaltern realism goes a long way towards explaining China's popularity with political elites in fragile developing countries. Many developing country regimes are stuck in nation building and fear domestic unrest. Therefore a development partner endorsing the status quo, like China, is more welcome than Western "partners" empowering civil society and oppositional movements.

Overall, constructivist theories appear most useful in explaining China's popularity in the Middle East and Africa, but international political economy (IPE) and realist theories point to economic considerations and state interests as important underlying drivers. 


\section{References}

Addis, Amsalu K., and Zhu Zuping. 2018. "Criticism of neo-colonialism: clarification of Sino-African cooperation and its implication to the west." Journal of Chinese Economic and Business Studies 16 (357-373).

Afrobarometer. 2016. China's growing presence in Africa wins positive popular reviews (press release, 24 October).

Al-Tamini, Naser M. 2014. China-Saudi Arabia Relations, 1990-2012. London and New York: Routledge.

Alden, Chris, and Cristina Alves. 2017. "China's regional forum diplomacy in the developing world: socialization and the 'Sinosphere'." Journal of Contemporary China 26 (104):151-165.

Alden, Chris, and Daniel Large. 2011. "China's exceptionalism and the challenges of delivering difference in Africa." Journal of Contemporary China 20 (68):21-38.

Alison, Graham. 2017. Destined for War: Can America and China Escape Thucydides' Trap? Boston: Houghton Mifflin.

Amin, Samir. 1976. Unequal Development: An Essay on the Social Formations of Peripheral Capitalism. New York: Monthly Review Press.

Arab Center. 2017. 2016 Arab Opinion Index. Washington, DC: Arab Center.

Arab Center. 2018. The 2017-2018 Arab Opinion Index. Washington, DC: Arab Center.

Ayoob, Mohammed. 2002. "Inequality and theorizing in International Relations: the case for subaltern realism." International Studies Review 4 (3):27-48.

Baum, Matthew A., and Philip B.K. Potter. 2008. "The relationships between mass media, public opinion, and foreign policy: toward a theoretical synthesis." Annual Review of Political Science 11:39-65.

BBC News. 2006. "Mbeki warns on China-Africa ties." 14 December.

Berger, Peter L., and Thomas Luckmann. 1966. The Social Construction of Reality: A Treatise in the Sociology of Knowledge. Garden City, NY: Doubleday.

Bodomo, Adams. 2018. "The bridge is not burning down: transformation and resilience within China's African diaspora communities." African Studies Quarterly 17 (4):6383.

BP. 2018. BP Statistical Review of World Energy, June 2018. London: BP.

Brautigam, Deborah. 2009. The Dragon's Gift: The Real Story of China in Africa. Oxford: Oxford University Press.

Campbell, Horace. 2008. "China in Africa: challenging US global hegemony." Third World Quarterly 29 (1):89-105.

Cardoso, Fernando Henrique, and Enzo Faletto. 1979. Dependency and Development in Latin America. Berkeley: University of California Press.

Clover, Charles, Emily Feng, and David Pilling. 2017. "Zimbabwe crisis turns spotlight on China's role in Africa." Financial Times, 21 November.

Erian, Stephanie. 2012. "China at the Libyan endgame." Policy 28 (1):49-52.

Fattah, Hassan M. 2006. "Avoiding political talk, Saudis and Chinese build trade." New York Times, 23 April.

Fioramonti, Lorenzo, and Patrick Kimunguyi. 2011. "Public and elite views on Europe vs. China in Africa." International Spectator 46 (1):69-82.

Frankel, James D. 2016. "Chinese-Islamic connections: an historical and contemporary overview." Journal of Muslim Minority Affairs 36 (4):569-583. 
Friedrichs, Jörg. 2016. "An intercultural theory of international relations: how self-worth underlies politics among nations." International Theory 8 (1):63-96.

Friedrichs, Jörg. 2017. "Sino-Muslim relations: the Han, the Hui, and the Uyghurs." Journal of Muslim Minority Affairs 37 (1):55-79.

Friedrichs, Jörg. 2018. "Intermestic security challenges: managing transnational bonds." European Journal of International Security 3 (2):162-186.

Garver, John W. 2006. China and Iran: Ancient Partners in a Post-Imperial World. Seattle: University of Washington Press.

Gilpin, Robert. 1981. War and Change in World Politics. Cambridge: Cambridge University Press.

Gries, Peter Hays. 1999. "A "China threat"? Power and passion in Chinese "face nationalism"." World Affairs 162 (2):63-75.

Hanauer, Larry, and Lyle J. Morris. 2014. Chinese Engagement in Africa: Drivers, Reactions, and Implications for U.S. Policy. Santa Monica: RAND Corporation.

Hanusch, Marek. 2012. "African perspectives on China-Africa: modelling popular perceptions and their economic and political determinants." Oxford Development Studies 40 (4):492-516.

Hayoun, Massoud. 2013. "Strange bedfellows: China's Middle Eastern inroads." World Affairs 175 (5):89-96.

He, Ming, and Shao-jie Zhang. 2011. "Re-conceptualizing the Chinese concept of face from a face-sensitive perspective." Journal of Pragmatics 43 (9):2360-2372.

Hess, Steve, and Richard Aidoo. 2014. "Charting the roots of anti-Chinese populism in Africa: a comparison of Zambia and Ghana." Journal of Asian and African Studies 49 (2):129-147.

Ho, David Yau-fai. 1976. "On the concept of face." American Journal of Sociology 81 (4):867-884.

Ho, Wai-Yip. 2013. "Mobilizing the Muslim minority for China's development: Hui Muslims, ethnic relations and Sino-Arab connections." Journal of Comparative Asian Development 12 (1):84-112.

Hong, Zhao. 2014. "China's dilemma on Iran: between energy security and a responsible rising power." Journal of Contemporary China 23 (87):408-424.

$\mathrm{Hu}$, Hsien Chin. 1944. "The Chinese concepts of "face"." American Anthropologist 46 (1):45-64.

Human Rights Watch. 2011. "You'll Be Fired if You Refuse." Labor Abuses in Zambia's Chinese State-owned Copper Mines New York: Human Rights Watch.

Iliffe, John. 2005. Honour in African History. Cambridge: Cambridge University Press.

Jacques, Martin. 2012. When China Rules the World: The Rise of the Middle Kingdom and the End of the Western World. 2nd ed. London: Penguin.

Kamel, Maha S. 2018. "China's Belt and Road Initiative: Implications for the Middle East." Cambridge Review of International Affairs 31 (1):76-95.

Keohane, Robert O. 1984. After Hegemony: Cooperation and Discord in the World Political Economy. Princeton, NJ: Princeton University Press.

Keohane, Robert O., and Joseph S. Nye. 1977. Power and Interdependence: World Politics in Transition. Boston: Little, Brown and Company.

Kertzer, Joshua D., and Thomas Zeitzoff. 2017. "A bottom-up theory of public opinion about foreign policy." American Journal of Political Science 61 (3):543-558.

Keskin, Tugrul, and Christian N. Braun. 2016. "When a sleeping giant wakes: a neoclassical realist analysis of China's expanding ties in the Middle East." Sociology of Islam 4 (1):1-26. 
Keuleers, Floor. 2015. "Explaining external perceptions: the EU and China in African public opinion." Journal of Common Market Studies 53 (4):803-821.

Krasner, Steven D. 1985. Structural Conflict: The Third World Against Global Liberalism. Berkeley: University of California Press.

Kurlantzick, Joshua. 2007. Charm Offensive: How China's Soft Power Is Transforming the World. New Haven: Yale University Press.

Kynge, James. 2018. "Chinese contractors grab lion's share of Silk Road projects." Financial Times, 24 January.

Lind, Jennifer, and Daryl G. Press. 2018. "Markets or mercantilism? How China secures its energy supplies." International Security 42 (4):170-204.

Mearsheimer, John R. 2006. "China's unpeaceful rise." Current History 105 (690):160-162.

Moravcsik, Andrew. 1997. "Taking preferences seriously: a liberal theory of international politics." International Organization 51 (4513-553).

Moravcsik, Andrew. 2011. "The New Liberalism." In The Oxford Handbook of Political Science, edited by Robert E. Goodin, 709-729. Oxford: Oxford University Press.

Morgenthau, Hans J. 1948. Politics Among Nations: The Struggle for Power and Peace. New York: Alfred A. Knopf.

Nkrumah, Kwame. 1965. Neocolonialism: The Last State of Imperialism. London: Nelson.

Norris, William J. 2016. Chinese Economic Statecraft: Commercial Actors, Grand Strategy, and State Control. Ithaca, NY: Cornell University Press.

Nye, Joseph S. 2004. Soft Power: The Means to Success in World Politics. New York: Public Affairs.

Nye, Joseph S. 2013. "What China and Russia Don't get about soft power." Foreign Policy:April 29.

Nye, Joseph S. 2015. Is the American Century Over? Cambridge: Polity.

Olimat, Muhamad S. 2014. China and the Middle East since World War II: A Bilateral Approach. Lanham, MD: Lexington.

Olimat, Muhamad S. 2016. China and North Africa since World War II: A Bilateral Approach. Lanham, MD: Lexington.

Organski, A.F.K. 1958. World Politics. New York: Knopf.

Pew Research Center. 2017. Globally, more name U.S. than China as world's leading economic power. Washington, DC: Pew Research Center.

Pew Research Center. 2018. Trump's international ratings remain low, especially among key allies: Most still want U.S. as top global power, but see China on the rise. Washington, DC: Pew Research Center.

Pilling, David, and Emily Peng. 2018. "China's Africa rail projects hit buffers." Financial Times, 7 December.

Pitt-Rivers, Julian. 1965. "Honour and social status." In Honour and Shame: The Values of Mediterranean Society, edited by John G. Péristiany, 19-77. London: Weidenfeld and Nicolson.

Qi, Xiaoying. 2011. "Face: a Chinese concept in a global sociology." Journal of Sociology 47 (3):279-295.

Rose, Gideon. 1998. "Neoclassical realism and theories of foreign policy." World Politics 51 (1):144-172.

Ryan, Fergus, Danielle Cave, and Nathan Ruser. 2018. Mapping Xinjiang's "Re-education" Camps. Barton: Australian Strategic Policy Institute.

Santana, Rebecca. 2009. "Iran: few words for China but plenty for Germany." Associated Press, 15 July.

Saudi Gazette. 2010. "Editorial: Sino-Arab cooperation." Saudi Gazette, 15 May. 
Sautman, Barry, and Hairong Yan. 2009. "African perspectives on China-Africa links." China Quarterly 199:728-759.

Schweller, Randall L. 2014. "China's aspirations and the clash of nationalisms in East Asia: a neoclassical realist examination." International Journal of Korean Unification Studies 23 (2):1-40.

Scobell, Andrew, and Alireza Nader. 2016. China in the Middle East: The Wary Dragon. Santa Monica: Rand.

Shambaugh, David. 2015. "China's soft-power push: the search for respect." Foreign Affairs (July/August).

Shichor, Yitzhak. 2014. "Respected and suspected: Middle Eastern perceptions of China's rise." In Asian Thought on China's Changing International Relations, edited by Niv Horesh and Emilian Kavalski, 123-140. Basingstoke: Palgrave Macmillan.

Shinn, David. 2016. "Extended ground for U.S.-China competition? Comparing China's and the U.S.' engagement with Africa." China Quarterly of International Strategic Studies 2 (1):35-55.

Simpfendorfer, Ben. 2011. The New Silk Road: How a Rising Arab World is Turning away from the West and Rediscovering China. Basingstoke: Palgrave Macmillan.

Smith, David. 2012. "China offers \$20bn of loans to African nations." The Guardian, 19 July.

Sørensen, Camilla T.N. 2013. "Is China becoming more aggressive? A neoclassical realist analysis." Asian Perspective 37 (3):363-385.

Soroka, Stuart N. 2003. "Media, public opinion, and foreign policy." Press/Politics 8 (1):2748.

Stewart, Frank Henderson. 1994. Honor. Chicago: University of Chicago Press.

Stout, Kristie Lu. 2016. "Blockbuster battle: Is China's movie industry the new Hollywood?" CNN, 23 June.

Strauss, Julia C. 2009. "The past in the present: historical and rhetorical lineages in China's relations with Africa." China Quarterly 199:777-795.

Sun, Degang, and Yahia A. Zoubir. 2015. "China's economic diplomacy towards the Arab countries: challenges ahead?" Journal of Contemporary China 24 (95):903-921.

Telhami, Shibley. 2013. The World Through Arab Eyes: Arab Public Opionion and the Reshaping of the Middle East. New York: Basic Books.

Tella, Oluwaseun. 2016. "Wielding soft power in strategic regions: an analysis of China's power of attraction in Africa and the Middle East." Africa Review 8 (2):133-144.

Waltz, Kenneth N. 1979. Theory of International Politics. Reading, MA: Addison Wesley.

Wang, Yiwei. 2008. "Public diplomacy and the rise of Chinese soft power." Annals of the American Academy of Political and Social Science 616:257-273.

Wendt, Alexander. 1992. "Anarchy is what states make of it: the social construction of power politics." International Organization 46 (2):391-407.

Wendt, Alexander. 1999. Social Theory of International Relations. Cambridge: Cambridge University Press.

Zhao, Suisheng. 2014. "A neo-colonialist predator or development partner? China's engagement and rebalance in Africa." Journal of Contemporary China 23 (90):10331052.

Zhu, Zhiqun. 2013. China's New Diplomacy: Rationale, Strategies and Significance. 2nd ed. London: Routledge. 